\title{
The Procyclicality of the Leverage Ratio in Turkish Banking Sector ${ }^{1}$
}

\author{
Dr. Sultan SARI \\ sarisultan51@gmail.com, ORCID: 0000-0002-8670-3625
}

\begin{abstract}
The leverage ratio is an important ratio, especially in the banking sector. In this study, it is researched whether the leverage ratio in Turkish banking sector is influenced from the procyclicality in the Turkish economy or how it is influenced. For this purpose, it is focused on leverage ratio and asset rate. As leverage ratio, it is used the external assets / total shareholder's equity rate and also the total assets / total shareholder's equity. As indicator for asset quality and change is used the total loans / total assets in Turkish banking sector. The relationship between the leverage ratios and the total loans / total asset rate in the condition of the all else being equal is analysed empirically as a whole with the quarterly banking cumulative sectorial data between 2007 - 2019 by ARDL ( Auto-Regresive Distributed Lag ) method for first time. According to the analysis results, there is a positive and statistically significant relationship between each of the leverage ratios and the total loans / total assets rate in the long run. It indicates that the leverage ratio is procyclical. It means that the leverage ratio increase and also the total loans / total assets rate in banking sector increase. To conclude, as the credit policy, it is recommended to determine countercyclical policy during financial expansion periods for the financial stability.
\end{abstract}

Keywords: Turkish banking, banking assets, leverage ratio, leverage procyclicality, ARDL method

JEL Codes: E20, G10, G21

\section{Introduction}

Banks are systemically important institutions in the financial markets and especially in the bank-based economies like Turkey. Because $84 \%$ of the financial sector's assets belongs to banks in Turkey in 2020. Furthermore, this rate increase clearly more when it is taken account all bank's financial shareholdings ( TBB, 2021: I-20 ). It means that banking plays an important role in shaping the economic structure of the country, expanding the markets and forming policies regarding financial markets by crediting and collecting funds in Turkey. Shortly, it directly affects macro economy and gets affected by it. For example, the procyclicality of financial system's leverage.

It is claimed that indicated that the leverage procyclicality is among the major reasons of especially the last Global Crisis and BASEL II utilized during this crisis period has failed to predict the risk. This procyclicality in financial expansion and contraction periods has wider impacts for developing economies especially such as Turkey ( referrer Terzioglu and Demir, 2015 ). Therefore, it is worth to interest always and to research it by different models and approaches.

Year 5/ 2021, Volume-5, Issue-2 | WWW.ispecjournal.org

1. This study presented orally in the BILTEK International Symposium-IV; held on April 12-13, 2021 at Gaziantep University, Nizip Faculty of Education, Gaziantep, Turkey. 
At first, it is necessary to describe "the leverage and leverage ratio" and "the procyclicality".

There is no any single description of "leverage" or "leverage measure". Actually and shortly, leverage is an investment strategy by using external resources the use of various financial instruments or to borrow. For example, banks borrow by different instruments (such as the most known deposits or credit from other financial institutions) to allocate credit and or to acquire more assets to profit, in other word, to increase their return on equity. Therefore, leverage ratio can be used as the debt ratio or indebtness indicator.

As D'Hulster ( 2009 : 1 ) describes; "leverage allows a financial institution to increase the potential gains or decrease losses on a position or investment beyond what would be possible through a direct investment of its own funds". According to her, there are three types of leverage: these are balance sheet leverage, economic leverage (based on market dependent future cash flows) and embedded leverage (based on market risk ).

The most used leverage ratio measures a bank's core capital relative to its total assets. According to Basel Committee ( $2014: 1$ ) ; "The Basel III leverage ratio is defined as the capital measure ( the numerator ) divided by the exposure measure ( the denominator ), with this ratio expressed as a percentage: Leverage ratio = Capital measure / Exposure measure". This is "embedded leverage" that expressed by D'Hulster ( 2009: 1 ). Banks can use all these kind of leverages for both micro and macro-prudential purposes. In this study, here, leverage is defined as the balance sheet leverage as the ratio of the external assets to shareholder's equity and as the ratio of total assets to shareholder's equity.

"Procyclicality" refers to "the tendency of financial variables to fluctuate around a trend during the economic cycle" (Landau, 2009). In its simplest form: "it refers to the interactions between the financial system and the real economy which are mutually reinforcing. Such interactions tend to amplify the amplitude of the business cycle, thereby heightening the risk to financial stability" (Nijathaworn, 2009 : 3). BIS ( the Bank for International Settlements, 2009a: 125 ) describes "procylicality" as " its dynamics and the dynamics of the real economy reinforcing each other, increasing the amplitude of booms and busts and undermining stability of both the financial sector and the real economy." Shortly, in another BIS (2008: 1) framework, it refers to "the mutually reinforcing mechanisms through which the financial system can amplify business fluctuations and possibly cause or exacerbate financial instability".

The relationship between leverage and procyclicality has been examined by many economists in the international arena with different approaches and methods. However, the literature related to cyclical leverage practices in Turkey received little attention. Recently, especially after Global Crisis, these interests increased. In these way, for example, according to Binici and Köksal (2012), Çalışkan (2011), Avcı and Çatak (2016), Kaya and Köksal (2019), the leverage ratio in banking sector is procyclical.

In this study, it is researched by different method whether the leverage ratio in Turkish banking sector is influenced from the procyclicality in the Turkish economy or how it is influenced. For this purpose, it is focused on leverage ratio and asset rate. In this way, after literature review, it is considered the method and data in the third part. As leverage ratio, it is used the external assets / total shareholder's equity rate and also the total assets / total

Year 5/ 2021, Volume-5, Issue-2 | WWW.ispecjournal.org

1. This study presented orally in the BILTEK International Symposium-IV; held on April 12-13, 2021 at Gaziantep University, Nizip Faculty of Education, Gaziantep, Turkey. 
shareholder's equity rate. As indicator for asset rate is used the total loans / total assets rate. The relationship between the leverage ratios and the total loans / total assets rate in the condition of the all else being equal ( ceteris paribus ) is analysed empirically as a whole with the quarterly Turkish banking cumulative sectorial data between 2007 - 2019 by ARDL (Auto-Regresive Distributed Lag) method or known bound test method for cointegration for first time as well. Section 4 presents empirical findings. The study finishes with a summary and conclusion section.

\section{Literature Review}

Many economists ( Adrian and Shin, 2008a ; 2008b ; 2010 ; Çalışkan, 2011 ; Binici and Köksal, 2012 ; Nuño and Thomas, 2013 ; Terzioglu and Demir, 2015 ; Wu and Hu, 2017 ; Kaya and Köksal, 2019 ) shows that the behaviour of banks is procyclical and this behaviour threatens macroeconomic and financial stability. It is believed that macroeconomic factors are behind each financial crisis, as financial institutions change their activities based on changing macroeconomic conditions as it is expressed by Adrian and Shin (2008b), Athanasoglou and Daniilidis (2011), Avc1 and Çatak (2016: 43) so the leverage ratio is procyclical.

It is claimed that contributes to the banking sector's procyclicality, in general, are the economic policy, the economic and financial environment and the regulatory framework of banks ( as referred Athanasoglou et al, 2013: 2 from VanHoose, 2008 ; Caprio, 2010). Moreover Hardouvelis (2010 : 1) also, categorize them into four groups in the same way:

1- The economic environment such as globalization, technological improvements, "shorttermism," and inertia in household and business sentiment,

2- The financial environment like the similarity of techniques and input data used to assess banking risk, risk management, the similarity of behaviour of fund managers, behaviour of rating agencies,

3- The policymaking environment such as the political pressures on regulators to behave in a way similar to the market and the powerful financiers or bias of policy makers in favour of the wealthy financial sector.

4- As the institutional features of the financial system, he gives example such as capital adequacy rules, bank provisioning, accounting, leverage and liquidity ratios, collateral and margin requirements, size of financial institutions, home versus host country regulation, market structure and organizations. Actually, as seen, it is considered twenty different factors contributing to procyclicality in this study.

According to Hardouvelis (2010: 2) as well, especially, in a fragile financial environment with private and public sector leverage, procyclicality becomes an even more important issue. Because it can aggravate economic fluctuations and leads to suboptimal behaviour and then financial behaviour in the emerging countries becomes itself procyclical for Hardouvelis (2010). For this reason, he refers 'the G- 20 countries' stricter definition of capital and higher capital requirements, with buffers which have countercyclical features and also their restrictions on financial institutions' liquidity and leverage".

Year 5/ 2021, Volume-5, Issue-2 | WWW.ispecjournal.org

1. This study presented orally in the BILTEK International Symposium-IV; held on April 12-13, 2021 at Gaziantep University, Nizip Faculty of Education, Gaziantep, Turkey. 
Adrian and Shin (2008b) study " the economic relationships between financial market liquidity, monetary policy, and credit cycles by investigating how financial intermediaries react to the changes in their balance sheets " and found some evidence to strong procyclical leverage for investment banks in United States of America ( USA ) ${ }^{1}$ that institutions increase their leverage during booms and reduce it during downturns and the expansion and contraction of balance sheets amplifies, rather than counteracts, the credit cycle. According to them, banks are very aware of changes in asset and the effects on leverage. When you look at the fluctuations in balance sheets, the main tool to adjust their leverage is "collateralized borrowing and lending in particular, repurchase agreements and reverse repurchase agreements, transactions in which the borrower of funds provides securities as collateral". As expressed by them, since leverage is related to value at risk, the banks' efforts to control risk and manage lead to procyclical leverage (Adrian and Shin, 2008b : 1, 3 ).

Damar et al (2010) research "the interaction of leverage procyclicality with the use of wholesale funding in Canadian financial institutions and how macroeconomic and market environments drive such interactions". The degree of procyclicality is not constant across different types of financial institutions and according to macroeconomic and market environments. Financial institutions that use wholesale funding display high degrees of procyclicality, because these market-based funds adjust quickly to macroeconomic and market environments. However, when the crisis reduced short-term wholesale funding markets, revealing the high funding liquidity risks of these funds, financial institutions loss the ability to adjust leverage easily and quickly, which decrease the degree of procyclicality. According to Damar et al (2010 : 26), although there is a regulation in Canada which limits the leverage ratio to prevent excessively high leverage, it does not directly control the change in leverage and so it could lead to aggregate volatility. On the other hand, it is suggested the Basel Committee's regulation on it because it enforce counter-cyclical capital holdings and directly restrict banks' balance-sheet liquidity-risk.

According to Kalemli-Ozcan et al (2011) the leverage ratio is procyclical for investment banks and for large commercial banks in the United States ( US ), but to a lesser extent for the banks in Europe. Their paper's main contribution is to help us understand patterns of leverage before the crisis. Their results may have important policy implications especially with regards to regulatory reform.

Nuño and Thomas (2013) studied the United States ( US ) leveraged financial sector too. Their leverage, equity and assets series are constructed using data from the US Flow of Funds for the period 1963: Q1 - 2011: Q3. They consider four leveraged financial subsectors ( US-chartered commercial banks, savings institutions, security brokers and dealers and finance companies ). Their empirical analysis shows firstly that the leverage ratio of the different subsectors display large fluctuations, contributing more than equity capital to cyclical movements in total assets. Secondly, leverage moves together negatively with equity and thirdly, positively with total assets. Finally, leverage is mildly procyclical with respect to GDP.

Baglioni et al (2013) analyse a large sample of European banks ( 77 commercial and investment banks operating in 18 European countries including continental Europe, Switzerland and the UK ) which have a systemic impact on financial markets as composing

${ }^{1}$ Market-based financial system.

Year 5/ 2021, Volume-5, Issue-2 | WwW.ispecjournal.org

1. This study presented orally in the BILTEK International Symposium-IV; held on April 12-13, 2021 at Gaziantep University, Nizip Faculty of Education, Gaziantep, Turkey. 
the Stoxx600 Banks index ${ }^{2}$ over the period January 2000 - December 2009 by regression model and robustness test. To conclude, they found that the leverage of mainly investment European banks is clearly procyclical while mainly commercial European banks are not.

$\mathrm{Wu}$ and $\mathrm{Hu}$ (2017) think as well that the leverage procyclical behavior of commercial banks is one of the important reasons for the burst of the financial crisis in 2008. In their study, they investigate the leverage cyclical behaviours on commercial banks in China and the affecting factors by using panels and dynamic panel models with commercial banks' data during the period of 2006 - 2015 and by using the ratio of a bank's total asset to the equity as bank leverage ratio. They found that the leverage of the commercial banks have showed procyclical behaviors and foreign capital banks have stronger procyclical behaviors during these periods. While the increase in bank leverage cases is faster during the economic upturn period, the decrease in bank leverage cases during the economic downturn period is slower.

Çalışkan's (2011) paper, attempts to explain how the Turkish financial system emerged from the global crisis with little or no damage by comparing it with the USA and for this purpose focus on banks' historical leverage ratios. The overall leverage ratio of the Turkish banking system is lower than the US especially after the 2001 crisis. Bank-level panel regressions using both annual and quarterly data covering 1994 - 2009 period reveal that similar to US banks, he shows that Turkish banks adjust leverage procyclically and a quantitatively smaller degree of leverage growth compared to US. In addition, he thinks that tight regulatory and supervisory reforms implemented in Turkey after the 2001 crisis significantly reduced leverage growth on the contrary to the financial deregulation trend in the US in the years before the global crisis.

Binici and Köksal (2012) study firstly whether leverage in the Turkish banking sector is procyclical and secondly, they consider the determinants of the bank capital structure and leverage. Although they say that the academic literature does not provide conclusive evidence on the procyclicality of leverage for financial firms, they shows that leverage of the Turkish banking sector is procyclical as well. In addition, they found that the relation between leverage and asset growth differs according to the business models of the banks. Procyclicality of the leverage indicates that the expansion and contraction of the bank balance sheets accelerate the credit cycles implying that bank leverage and business cycles are related (Binici and Köksal, 2012: 23).

Avc1 and Çatak (2016) investigates the determinants of bank capital structure and procyclical behaviour of leverage by a panel data analysis with data between 2005 - 2014 in order to find out the relation between different type of leverage ratios and asset growth of banks. Furthermore, possible impacts of bank specific and macroeconomic variables on the bank capital structure are discussed. Their paper concludes that there is a positive relationship between asset growth and leverage and as a result Turkish banks' leverage is procyclical. It increases the financial system cyclicality and so can lead to financial instability in the economy.

Terzioglu and Demir's (2015) study is about the procyclicality of leverage ratios for top ten deposit banks in Turkey by focusing on the association between change in total assets

\footnotetext{
2 According to them, this index represents the largest European companies in the banking sector as defined by the Industry Classification Benchmark

Year 5/ 2021, Volume-5, Issue-2 | WWW.ispecjournal.org

1. This study presented orally in the BILTEK International Symposium-IV; held on April 12-13, 2021 at Gaziantep University, Nizip Faculty of Education, Gaziantep, Turkey.
} 
and leverage ratios by using the least square method with quarterly data between December 2002 and December 2014. The study concluded that leverage ratios in Turkish banking sector is procyclical and leverage procyclicality can be implemented as a market control mechanism for Turkey.

Kaya and Köksal (2019) are other researchers who investigate the procyclicality of the leverage for Turkish banks including deposits banks, Islamic banks and development banks. They study the relationship between the changes of leverage ratio and asset with data 2006 January - 2018 January by regression analysis. Their study indicates as well that the asset change affects the leverage rate change positively and statistically significantly.

\section{Model and Data}

In this study, the relations between leverage ratio and asset rate ( total credits / total assets) is analysed with Autoregressive Distributed Lag (ARDL) model. Autoregressive distributed lag (ARDL) model developed by Pesaran et al (2001) is one of the most general dynamic unrestricted model in econometric literature. ARDL method which the lagged values both of dependent and independent variables used as regressor is based on the standard least square method (Özdamar, 2015: 84). However, there are 3 steps mainly in ARDL cointegration technique or bound test of cointegration. In the first step, it is investigated whether there is a cointegration relationship between the variables included the analysis. In the existence of a cointegration relation among variables (serials), in the second step, it is considered the long run relationship by restricted error correction model ${ }^{3}$ and the short run relationship by error correction model (ECM) in the last step.

These models reduce the probability of spurious regression and eliminate the chances of spurious regression. Accordingly, $y_{t}$ dependent variable $, x_{j, t} \mathrm{j}=1,2, \ldots, \mathrm{k}$ independent variables $\operatorname{ARDL}\left(\mathrm{p}, q_{1}, q_{2}, ., q_{k}\right)$ model :

$y_{t}=\alpha_{0}+\alpha_{1} t+\sum_{i=1}^{p} \varphi_{i} y_{t-i}+\sum_{j=1}^{k} \sum_{l_{j=0}}^{q_{j}} \beta_{j l_{j}} x_{j, t-l_{j}}+\varepsilon_{t}$

$\alpha_{0}$ constant term,

$\alpha_{1}$ linear trend coefficent,

$\varphi_{i}$ coefficents of lagged dependent variables $(\mathrm{i}=1, \ldots \ldots, \mathrm{p})$

$\beta_{j l_{j}} \mathrm{k}$ coefficents of lagged independent variables ,

$\varepsilon_{t}$ ise error term

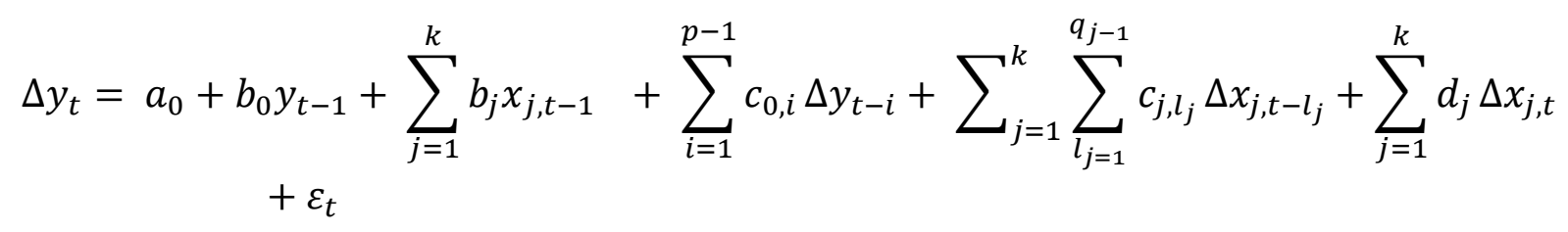

\footnotetext{
3 Anyway, there are 5 restricted error correction model ( 5 cases model) : these are Case 1( noconstant, no trend), Case 2 (restricted constant and no trend), Case 3 ( unrestricted constant and no trend ), Case 4 ( unrestricted constant and restricted trend ) and Case 5 ( unrestricted constant and unrestricted trend ) ( referrer Mert ve Çağlar: 280).
}

Year 5/ 2021, Volume-5, Issue-2 | WWW.ispecjournal.org

1. This study presented orally in the BILTEK International Symposium-IV; held on April 12-13, 2021 at Gaziantep University, Nizip Faculty of Education, Gaziantep, Turkey. 
Error correction model; $\mathrm{EC}_{\mathrm{t}}=\mathrm{y}_{\mathrm{t}}-\sum_{\mathrm{j}=1}^{\mathrm{k}} \frac{\mathrm{b}_{\mathrm{j}}}{\mathrm{b}_{0}} \mathrm{x}_{\mathrm{j}, \mathrm{t}}$

To investigate the cointegration relation between serials, $H_{0}: b_{0}=b_{j}=0, \forall_{j}$ ( no cointegration hypothesis test by $\mathrm{F}$ test. Critical values is given as table by Pesaran et al (2001). If F value > Upper critical value for I(1), the hypothesis of "nocointegration" will be rejected and decided that there is a cointegration relation between variables. For unrestricted models ( Case 1, 3 ve 5 ), it must be looked at $t$ values. With t-bound test, it is tested whether error correction coefficent is significant statistically or not. First of all data must be tested for unit root. Although ARDL cointegration technique does not require pre-testing for unit roots, this testing is necessary " to avoid ARDL model crash in the presence of integrated stochastic trend of I(2)", to avoid the possibility of spurious regression as expressed (Nkoro and Uko, 2016: 69). Because the bounds test is based on the assumption that the variables are $\mathrm{I}(0)$ or I(1) so if they are I(2) variables, F-statistics provided by Pesaran et al. (2001) becomes invalid (Ouattara, 2004a: 9; 2004b: 4-5). Similarly other diagonistic tests are applied to detect serial correlation, heterosedasticity, specification problems, normality problems ( Mert and Çağlar, 2019: 280 ; Hasan and Nasir, 2008: 505).

As leverage ratio, it is used the external assets / total shareholder's equity rate and also the total assets / total shareholder's equity as used often in the literature ( Terzioglu and Demir, 2015: 548 ; Binici and Köksal, 2012: 15 ; Kaya and Köksal, 2013: 13, Wu and Hu, 2017: 142 ). The leverage ratio does not include off-balance sheet exposure and also it is assumed that other things are equal (ceteris paribus). The variables used in the study are defined in Table 1 below and also their graph hereinafter.

Table 1. Variables and Resources

\begin{tabular}{|l|l|l|}
\hline Variables & Definition & Resource \\
\hline LR1 & $\begin{array}{l}\text { Leverage Ratio 1 ( External Assets / } \\
\text { Total Shareholder's Equity ) }\end{array}$ & $\begin{array}{l}\text { Banking Regulation and } \\
\text { Supervision Agency (BRSA) } \\
\text { Ratios }\end{array}$ \\
\hline LR2 & $\begin{array}{l}\text { Leverage Ratio 2 ( Total Assets / } \\
\text { Total Shareholder's Equity) }\end{array}$ & $\begin{array}{l}\text { It is derived from BRSA } \\
\text { Banking Balance-Sheet }\end{array}$ \\
\hline CRDAST & Total Credits / Total Assets & $\begin{array}{l}\text { It is derived from BRSA } \\
\text { Banking Balance-Sheet }\end{array}$ \\
\hline
\end{tabular}

Year 5/ 2021, Volume-5, Issue-2 | WWW.ispecjournal.org

1. This study presented orally in the BILTEK International Symposium-IV; held on April 12-13, 2021 at Gaziantep University, Nizip Faculty of Education, 

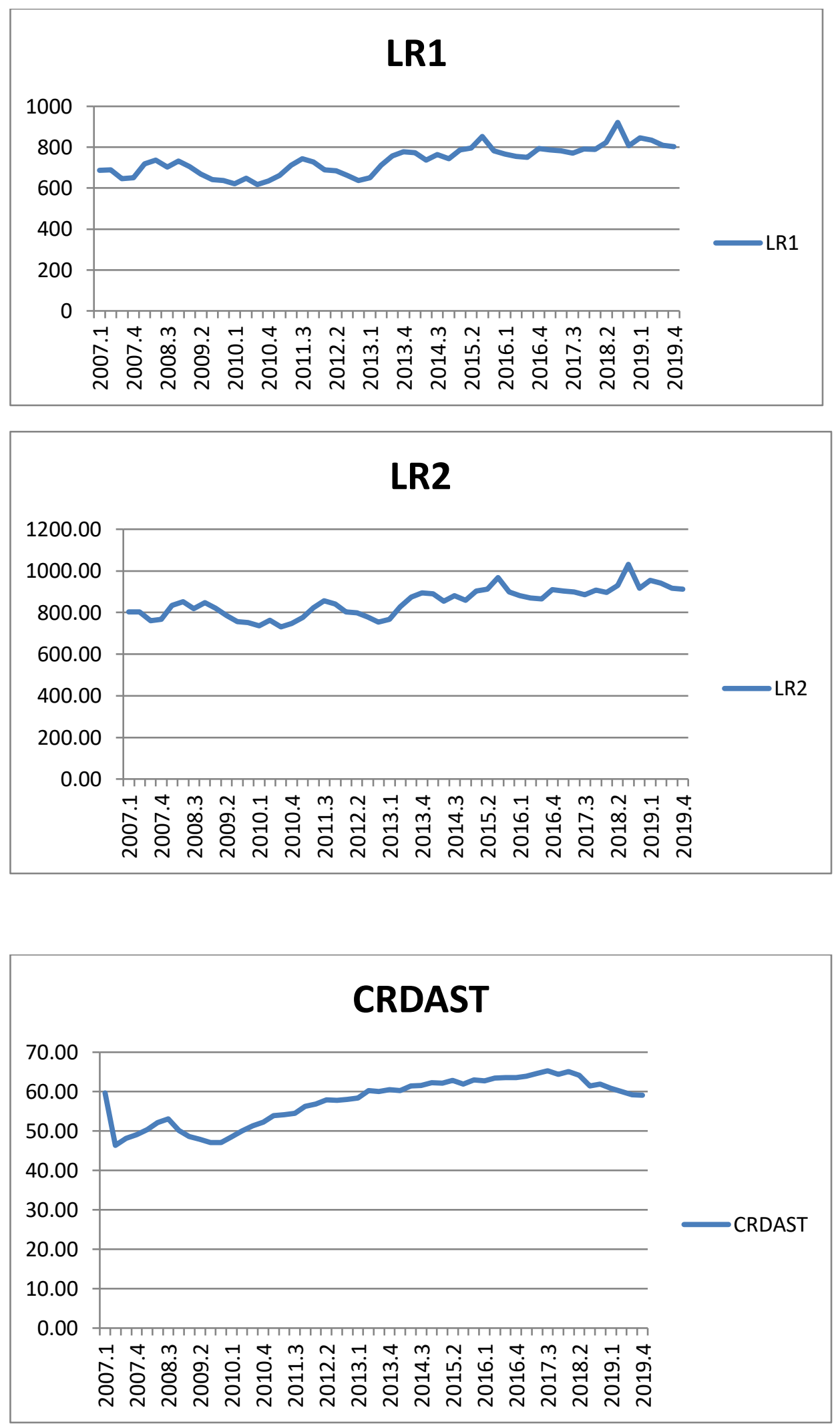

It is expressed that for European banks and US investment banks, balance sheet leverage began to increase around 2003 and it reached the peak in 2007 (BIS, 2009b: 3). Unlike European banks and US investment banks, as illustrated in these line graphs above, Year 5/ 2021, Volume-5, Issue-2 | WWW.ispecjournal.org 
there is a downward trend in the leverage ratios in the end of 2007 in Turkish banking sector. Then between $2009-2012$, there can be seen some small fluctuations around $700-800$. However, they reached some peaks in 2015 and in 2018. For example, while CRDAST peak is in the third quarterly period in 2017, the LR1 is 921.26 in the third period in 2018 and LR2 is 1031.23. It indicates fragility in the macro economy. The most important stress is that all these graphs are almost in the same direction. That is a predictor before empirical analysis for Turkish banking sector.

\section{Empirical Findings}

As expressed above, although ARDL cointegration method does not require pretesting for unit roots, this testing is necessary "to avoid ARDL model crash in the presence of integrated stochastic trend of I(2)". In this way, at first, all variables (all serials) was tested whether has a unit root or to test for stationarity. There are various methods to test unit root like Dickey-Fuller test (DF), Augmented Dickey-Fuller (ADF) test, Philip-Perron (PP) test and Kwiatkowski, Phillips, Schmidt, Shin (KPSS) test. It is is preferred The Augmented Dickey-Fuller (ADF) test there because of being the most commonly used unit root test in the time series analysis in the literature. Its results are reported in the Table 2. As have seen below, although all variables is not stationary for level for $\mathrm{I}(0)$, they are stationary for first difference or for $\mathrm{I}(1)$.

Table 2. Unit Root Test Results

\begin{tabular}{|c|c|c|c|c|c|c|}
\hline \multicolumn{4}{|l|}{ Level } & \multirow{2}{*}{\multicolumn{3}{|c|}{$\begin{array}{l}\text { 1st Difference } \\
\text { ADF ( H0: Serial has a unit root ) }\end{array}$}} \\
\hline & \multicolumn{3}{|c|}{ ADF ( H0: Serial has a unit root ) } & & & \\
\hline & Test Sta. & $\begin{array}{l}.05 \text { critical } \\
\text { value }\end{array}$ & Stationarity* & Test Stat. & $\begin{array}{l}.05 \text { critical } \\
\text { value }\end{array}$ & Stationarity* \\
\hline Variable & Intercept & Intercept & & Intercept & Intercept & \\
\hline LR1 & $-1,87$ & \multirow{3}{*}{$-2,92$} & Not Stationary & $-8,02$ & \multirow{3}{*}{$-2,92$} & Stationary \\
\hline LR2 & $-1,92$ & & Not Stationary & $-8,06$ & & Stationary \\
\hline CRDAST & $-1,31$ & & Not Stationary & $-4,41$ & & Stationary \\
\hline
\end{tabular}

*over Intercept stat.

\subsection{Model 1}

In for the dependant variable is LR1, for the independant variable is CRDAST, for ARDL ( p,q1,q2,q3 ) Model 1 by the maximum lag length 3, it is produced ARDL ( 2, 2 ) over Case 3 error correction model ( Unrestricted Constant and No Trend ). The Model 1 is chosen within 12 model by using Akaike Info Criterion. As seen in the Table 3 below, the most of the Model 1 coefficients is statistically significant.

Year 5/ 2021, Volume-5, Issue-2 | WwW.ispecjournal.org

1. This study presented orally in the BILTEK International Symposium-IV; held on April 12-13, 2021 at Gaziantep University, Nizip Faculty of Education, Gaziantep, Turkey. 
Table 3. ARDL Model 1

\begin{tabular}{|lrlrr|}
\hline \hline \multicolumn{1}{|c}{ Variable } & Coefficient & Std. Error & t-Statistic & Prob. \\
\hline \hline LR1(-1) & 0.680840 & 0.136121 & 5.001713 & 0.0000 \\
LR1(-2) & -0.144462 & 0.131373 & -1.099633 & 0.2775 \\
CRDAST & -13.68931 & 4.668179 & -2.932473 & 0.0053 \\
CRDAST(-1) & 19.51045 & 4.990457 & 3.909552 & 0.0003 \\
CRDAST(-2) & -1.983417 & 2.237367 & -0.886496 & 0.3802 \\
C & 125.8020 & 54.58743 & 2.304595 & 0.0260 \\
\hline \hline Adjusted R-squared & 0.811123 & Akaike info criterion & 9.788637 \\
F-statistic & 43.08550 & Schwarz criterion & 10.01808 \\
Prob ( F-statistic ) & 0.000000 & Hannan - Quinn criter. & 9.876010 \\
& & & & \\
\hline
\end{tabular}

Then, all diagonistic tests are implemented to model to investigate whether there are serial correlation, heterosedasticity, specification errors, normality problems or not as expressed before ( Mert and Çağlar, 2019: 280 ; Hasan and Nasır, 2008: 505 ). Table 4 reports the diagnostic test results. As have seen in the Table 4, there are not serial correlation, heterocedasticity, specification errors and normality problems in the Model 1.

Table 4. Model 1 Diagnostic Tests

\begin{tabular}{|l|l|l|l|}
\hline Purpose & Test & F & P \\
\hline Serial Correlation & Breush - Godfrey & 2,12 & 0,09 \\
\hline Model specification & Ramsey RESET & 2,45 & 0,12 \\
\hline Heterosedasticity & Breush - Pagan- Godfrey & 0,35 & 0,87 \\
\hline Normality & Jarque - Bera $=0,68$ & & 0,71 \\
\hline
\end{tabular}

Moreover, it is applied CUSUM and CUSUMSQ test whether there is significant break-point in the estimation or not. According to their plots as seen below, there are not significant break-points in the data of the Model 1. The CUSUM and CUSUMSQ lines are within the boundaries of the $95 \%$ confidence level and it indicates no deviations in the data set. 


\section{ISSN 2717-7262 ISPEC Journal of Social Sciences \& Humanities}
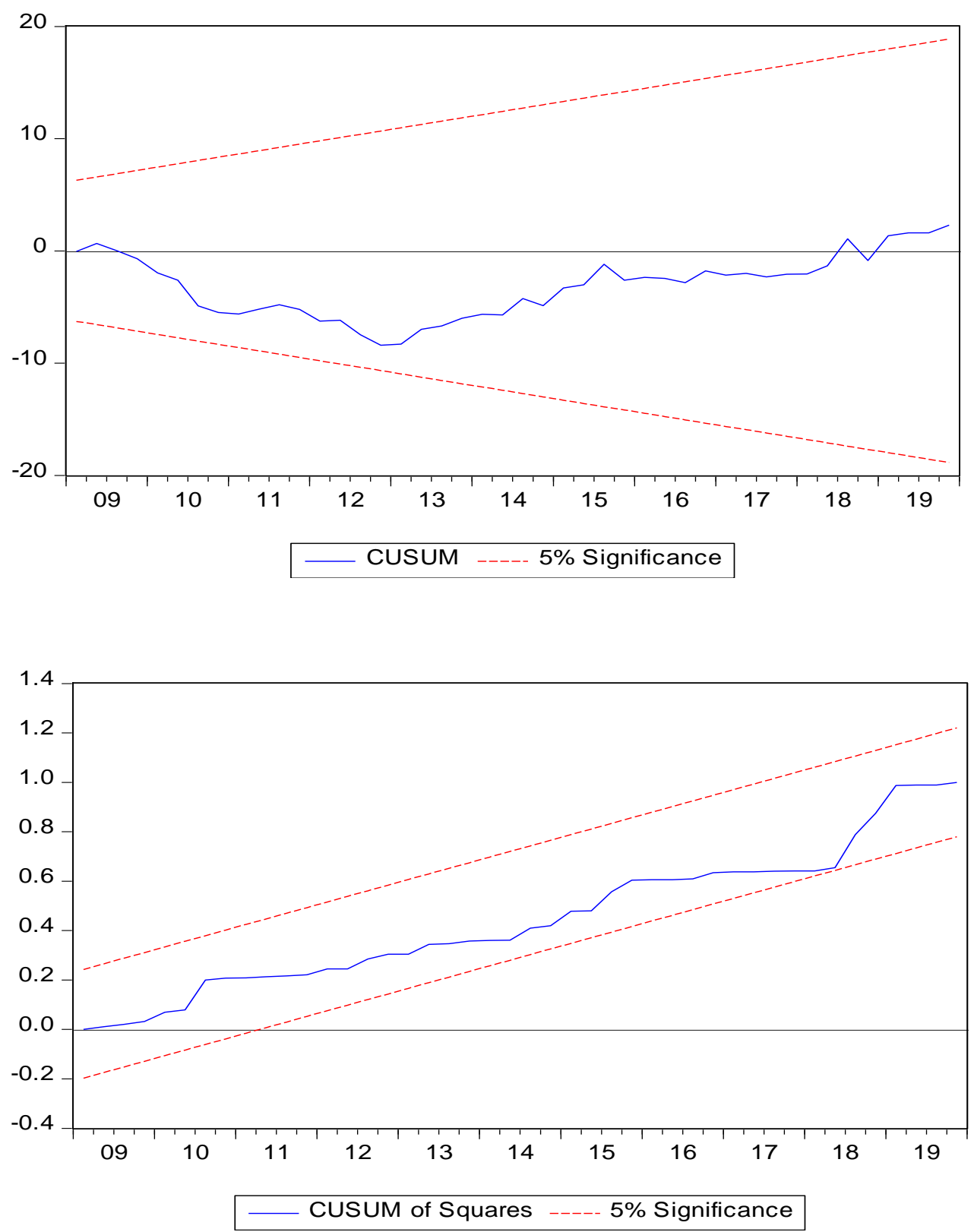

Table 5 reports the results of the bound tests shows below. As known, the bounds test result indicates whether there is a long-run relationship among the variables. 
Table 5. Bound Tests Results

\begin{tabular}{|c|c|c|c|c|}
\hline \multirow{2}{*}{\begin{tabular}{|l} 
F-Bounds Test \\
Test Statistic
\end{tabular}} & \multirow[b]{2}{*}{ Value } & \multicolumn{3}{|c|}{ Null Hypothesis: No levels relationship } \\
\hline & & Signif. & $\mathrm{I}(0)$ & $\mathrm{I}(1)$ \\
\hline & & \multicolumn{3}{|c|}{$\begin{array}{l}\text { Asymptotic: } \\
n=1000\end{array}$} \\
\hline F-statistic & 8.621294 & $10 \%$ & 4.04 & 4.78 \\
\hline \multirow[t]{4}{*}{$\mathrm{k}$} & 1 & $5 \%$ & 4.94 & 5.73 \\
\hline & & $2.5 \%$ & 5.77 & 6.68 \\
\hline & & $1 \%$ & 6.84 & 7.84 \\
\hline & \multirow[t]{4}{*}{50} & \multicolumn{3}{|c|}{$\begin{array}{c}\text { Finite } \\
\text { Sample: } \\
n=50\end{array}$} \\
\hline \multirow{3}{*}{ Actual Sample Size ${ }^{4}$} & & $10 \%$ & 4.19 & 4.94 \\
\hline & & $5 \%$ & 5.22 & 6.07 \\
\hline & & $1 \%$ & 7.56 & 8.685 \\
\hline t-Bounds Test & \multicolumn{4}{|c|}{ Null Hypothesis: No levels relationship } \\
\hline Test Statistic & Value & Signif. & $\mathrm{I}(0)$ & $\mathrm{I}(1)$ \\
\hline \multirow[t]{4}{*}{ t-statistic } & -4.152276 & $10 \%$ & -2.57 & -2.91 \\
\hline & & $5 \%$ & -2.86 & -3.22 \\
\hline & & $2.5 \%$ & -3.13 & -3.5 \\
\hline & & $1 \%$ & -3.43 & -3.82 \\
\hline
\end{tabular}

As seen in the table above, the F-statistics of 8.62 is greater than the upper bounds critical value of 7.84 and so it leads to rejecting the null hypothesis of no long-run relationship. Furthermore, as expressed above, for unrestricted models (Case 1, 3 and 5), it must be looked at $t$ values. With t-bound test, it is tested whether error correction coefficient is significant statistically or not. Even t-statistic of 4.15 as absolute value is greater than the upper bounds critical value of 3.82 for the significance level of $1 \%$ as absolute value. Thus, there is a long run cointegration relationship between serials. The Table 6 below reports the long-run estimations.

\section{Table 6. Long-Run Estimations for Model 1}

\begin{tabular}{|ccccc|}
\hline \multicolumn{5}{|c|}{ Levels Equation } \\
Case 3: Unrestricted Constant and No Trend & \\
\hline \hline Variable & Coefficient & Std. Error & t-Statistic & Prob. \\
\hline \hline CRDAST & 8.277693 & 1.703450 & 4.859371 & 0.0000 \\
\hline \hline EC $=$ LR1 $-(8.2777 *$ CRDAST $)$ & & & \\
\hline
\end{tabular}

\footnotetext{
${ }^{4}$ This critical values are calculated for small sample by Narayan (2005: 1987- 1990 ).

Year 5/ 2021, Volume-5, Issue-2 | wwW.ispecjournal.org

1. This study presented orally in the BILTEK International Symposium-IV; held on April 12-13, 2021 at Gaziantep University, Nizip Faculty of Education, 
According to the Model 1, there is a positive relationship LR1 and CRDAST. In other word, two variables move together. It shows when credits ( loans ) increase, for example in the output boom, LR1 ( external assets / total shareholder's equity ) also increase. Because banks operate to profit and so they want to increase their profits in the output boom. Since their main operations is crediting to profit, to be able to allocate credits, they increase either equity or external assets (foreign resources). It leads to that the leverage ratio ( external assets / total shareholder's equity ) for Turkish banks changes in the same direction with total credits / total assets ratio. In sum, LR1 for Turkish banking sector is procyclical. Hence, it can be concluded that Turkish banks change their activities based on changing macroeconomic conditions as found by Çalışkan (2011), Binici and Köksal (2012), Terzioglu and Demir (2015), Kaya and Köksal (2019).

As known, in the ARDL method, the short-run relationship is investigated by the error correction mechanism (ECM) as last step. The short-run estimate or error correction results of the Model 1 can be seen in Table 7.

Table 7. The Short-Run Estimations for Model 1

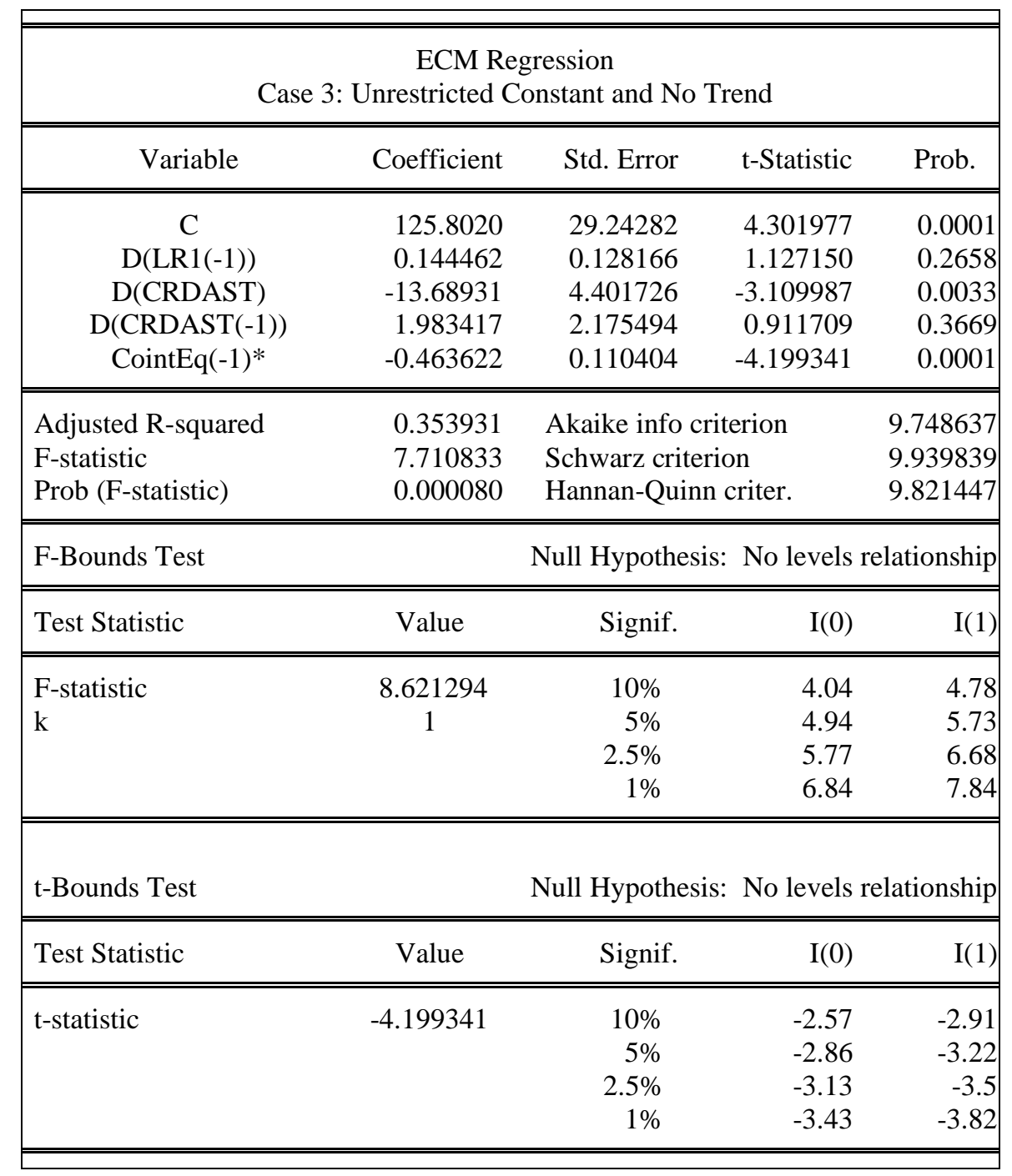

Year 5/ 2021, Volume-5, Issue-2 | WWW.ispecjournal.org

1. This study presented orally in the BILTEK International Symposium-IV; held on April 12-13, 2021 at Gaziantep University, Nizip Faculty of Education, Gaziantep, Turkey. 
As seen, ECT (Error Correction Term) (-1) is negative and significant as expected. This confirms the existence of the cointegration relationship among the variables. ECT (-1) is equal to (-0.46). In other words, according to Model 1, the short-run imbalances are eliminated in the long-run and the system is converging to the long-run equilibrium. According to Model 1, 46\% of the short-term imbalances are eliminated every two periods (6 months). In addition, as seen, in each period, the adjustment is in the opposite direction. Thus, (according to this model), when CRDAST is below its equilibrium value, the adjustment is upward, as might be (Greene, 2002: 580 ).

\subsection{Model 2}

In for the dependent variable is LR2, for the independent variable is CRDAST, for ARDL ( p,q1,q2,q3 ) Model 1 by the maximum lag length 3, it is produced ARDL ( 2, 2 ) over Case 3 error correction model ( unrestricted constant and no trend ). The Model 2 is chosen within 12 models by using Akaike Info Criterion ( AIC ). As have seen below, the most of the Model 2 coefficients is statistically significant.

Table 8. ARDL Model 2

\begin{tabular}{|crlrr|}
\hline \hline Variable & Coefficient & Std. Error & t-Statistic & Prob.* \\
\hline \hline LR2(-1) & 0.666128 & 0.135333 & 4.922132 & 0.0000 \\
LR2(-2) & -0.152492 & 0.130416 & -1.169268 & 0.2486 \\
CRDAST & -13.94210 & 4.620964 & -3.017141 & 0.0042 \\
CRDAST(-1) & 19.84228 & 4.945063 & 4.012542 & 0.0002 \\
CRDAST(-2) & -1.926769 & 2.219931 & -0.867941 & 0.3901 \\
C & 190.2292 & 62.65551 & 3.036113 & 0.0040 \\
\hline \hline Adjusted R-squared & 0.808669 & Akaike info criterion & 9.771702 \\
F-statistic & 42.42026 & Schwarz criterion & 10.00114 \\
Prob ( F-statistic ) & 0.000000 & Hannan-Quinn criter. & 9.859075 \\
\hline
\end{tabular}

All diagnostic tests are applied to detect serial correlation, heterosedasticity, specification errors, and normality problems to model. As reported in the Table 9, there are not serial correlation, heterocedasticity, specification errors and normality problems in the Model 2 too.

Table 9. Model 2 Diagnostic Tests

\begin{tabular}{|l|l|l|l|}
\hline Purpose & Test & F & P \\
\hline Serial Correlation & Breush - Godfrey & 2,18 & 0,08 \\
\hline Model specification & Ramsey RESET & 2,25 & 0,14 \\
\hline Heterosedasticity & Breush - Pagan - Godfrey & 0,39 & 0,85 \\
\hline Normality & Jarque - Bera $=0,70$ & & 0,7 \\
\hline
\end{tabular}

Year 5/ 2021, Volume-5, Issue-2 | WWW.ispecjournal.org

1. This study presented orally in the BILTEK International Symposium-IV; held on April 12-13, 2021 at Gaziantep University, Nizip Faculty of Education, 
According to the plots of CUSUM and CUSUMSQ, as seen below, there are not significant break-points in the data of the Model 2. The CUSUM and CUSUMSQ lines are within the boundaries of the $95 \%$ confidence level.
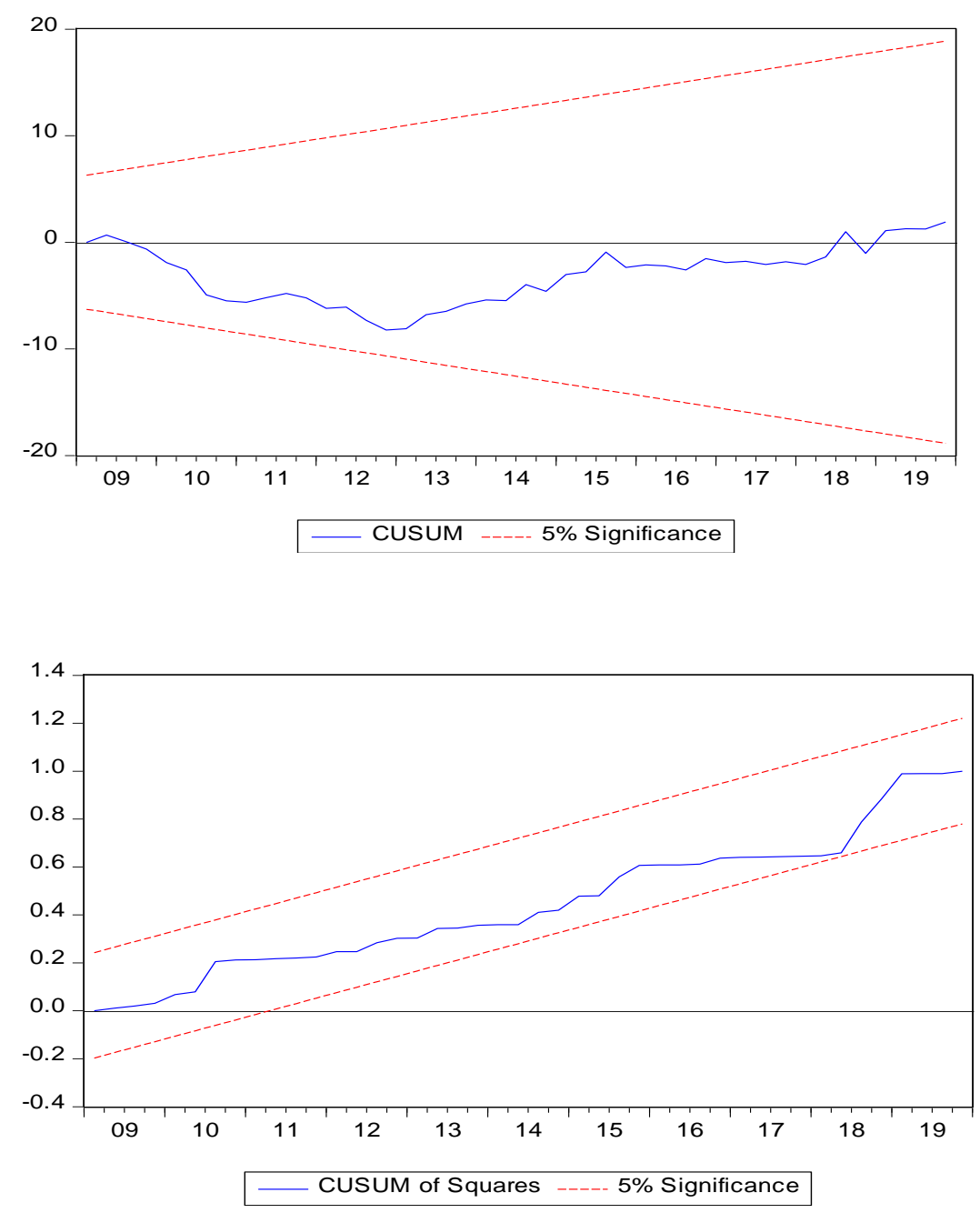

The Table 10 below reports the results of the bound tests for cointegration for Model 2. As known, the bounds test result indicates whether there is a long-run relationship between the variables. 
Table 10. Bound Tests Results

\begin{tabular}{|c|c|c|c|c|}
\hline \multicolumn{2}{|l|}{ F-Bounds Test } & \multicolumn{3}{|c|}{ Null Hypothesis: No levels relationship } \\
\hline \multirow[t]{2}{*}{ Test Statistic } & Value & Signif. & $\mathrm{I}(0)$ & $\mathrm{I}(1)$ \\
\hline & & \multicolumn{3}{|c|}{$\begin{array}{l}\text { Asymptotic: } \\
\text { n=1000 }\end{array}$} \\
\hline F-statistic & 9.203219 & $10 \%$ & 4.04 & 4.78 \\
\hline \multirow[t]{3}{*}{$\mathrm{k}$} & 1 & $5 \%$ & 4.94 & 5.73 \\
\hline & & $2.5 \%$ & 5.77 & 6.68 \\
\hline & & $1 \%$ & 6.84 & 7.84 \\
\hline & \multirow[t]{4}{*}{50} & \multicolumn{3}{|c|}{$\begin{array}{c}\text { Finite } \\
\text { Sample: } \\
n=50\end{array}$} \\
\hline \multirow{3}{*}{ Actual Sample Size } & & $10 \%$ & 4.19 & 4.94 \\
\hline & & $5 \%$ & 5.22 & 6.07 \\
\hline & & $1 \%$ & 7.56 & 8.685 \\
\hline t-Bounds Test & & \multicolumn{3}{|c|}{ Null Hypothesis: No levels relationship } \\
\hline Test Statistic & Value & Signif. & $\mathrm{I}(0)$ & $\mathrm{I}(1)$ \\
\hline \multirow[t]{4}{*}{ t-statistic } & -4.290230 & $10 \%$ & -2.57 & -2.91 \\
\hline & & $5 \%$ & -2.86 & -3.22 \\
\hline & & $2.5 \%$ & -3.13 & -3.5 \\
\hline & & $1 \%$ & -3.43 & -3.82 \\
\hline
\end{tabular}

As seen in the Table 10, the F-statistics of 9.20 is greater than the upper bounds critical value of 7.84. It leads to rejection to the null hypothesis of no long-run relationship ${ }^{5}$. However, for unrestricted model ( Case 3 ), it must be looked at t values. Even t-statistic of 4.29 as absolute value is bigger than the upper bounds critical value of 3.82 as absolute value. Thus, there is a long run cointegration relationship between variables. The Table 11 below presents the long-run estimations.

Table 11. Long-Run Estimations for Model 2

\begin{tabular}{|ccccc|}
\hline \multicolumn{5}{|c|}{ Levels Equation } \\
Case 3: Unrestricted Constant and No Trend \\
\hline \hline Variable & Coefficient & Std. Error & t-Statistic & Prob. \\
\hline \hline CRDAST & 8.169620 & 1.609346 & 5.076361 & 0.0000 \\
\hline \hline EC $=$ LR2 $-(8.1696 *$ CRDAST $)$ & & & \\
\hline
\end{tabular}

\footnotetext{
${ }^{5}$ Even according to the critical values which calculated for small sample by Narayan ( $2005: 1987$ - 1990 ), the F-statistics of 9.20 is greater than the upper bounds critical value of 8.68 as illustrated in the Table 10 .

Year 5/ 2021, Volume-5, Issue-2 | wWw.ispecjournal.org

1. This study presented orally in the BILTEK International Symposium-IV; held on April 12-13, 2021 at Gaziantep University, Nizip Faculty of Education, 
According to the Model 2, CRDAST affects in the positive direction and statistically significantly LR2 ( total assets / total shareholder's equity ). It shows when the credits increase ( for example in the boom ), total assets increase and so increase the ratio of total assets to total shareholder's equity. Hence, the leverage ratio for Turkish banking sector is procyclical. It means that the leverage ratio for Turkish banks changes in the same direction with total credits / total assets rate. In other words, Turkish banks change their activities based on changing macroeconomic conditions as found by Çalışkan (2011), Binici and Köksal (2012), Terzioglu and Demir (2015), Kaya and Köksal (2019).

As expressed before above, in the ARDL method, the short-run relationship is considered by the error correction mechanism (ECM) as last step. The short-term estimations of the Model 2 can be seen in Table 12.

Table 12. The Short-Run Estimations for Model 2

\begin{tabular}{|c|c|c|c|c|}
\hline \multicolumn{5}{|c|}{$\begin{array}{c}\text { ECM Regression } \\
\text { Case 3: Unrestricted Constant and No Trend }\end{array}$} \\
\hline Variable & Coefficient & Std. Error & t-Statistic & Prob. \\
\hline $\mathrm{C}$ & 190.2292 & 43.06480 & 4.417279 & 0.0001 \\
\hline $\mathrm{D}(\mathrm{LR} 2(-1))$ & 0.152492 & 0.127397 & 1.196985 & 0.2377 \\
\hline $\mathrm{D}(\mathrm{CRDAST})$ & -13.94210 & 4.361821 & -3.196395 & 0.0026 \\
\hline $\mathrm{D}(\mathrm{CRDAST}(-1))$ & 1.926769 & 2.156755 & 0.893365 & 0.3765 \\
\hline CointEq(-1)* & -0.486364 & 0.112098 & -4.338752 & 0.0001 \\
\hline Adjusted R-squared & 0.369120 & \multirow{3}{*}{\multicolumn{2}{|c|}{$\begin{array}{l}\text { Akaike info criterion } \\
\text { Schwarz criterion } \\
\text { Hanna - Quinn critter. }\end{array}$}} & 9.731702 \\
\hline F-statistic & 8.167310 & & & 9.922904 \\
\hline Prob ( F-statistic ) & 0.000049 & & & 9.804513 \\
\hline F-Bounds Test & & \multicolumn{3}{|c|}{ Null Hypothesis: No levels relationship } \\
\hline Test Statistic & Value & Signify. & $\mathrm{I}(0)$ & $\mathrm{I}(1)$ \\
\hline F-statistic & 9.203219 & $10 \%$ & 4.04 & 4.78 \\
\hline \multirow[t]{3}{*}{$\mathrm{k}$} & 1 & $5 \%$ & 4.94 & 5.73 \\
\hline & & $2.5 \%$ & 5.77 & 6.68 \\
\hline & & $1 \%$ & 6.84 & 7.84 \\
\hline t-Bounds Test & & \multicolumn{3}{|c|}{ Null Hypothesis: No levels relationship } \\
\hline Test Statistic & Value & Signify. & $\mathrm{I}(0)$ & $\mathrm{I}(1)$ \\
\hline \multirow[t]{4}{*}{ t-statistic } & -4.338752 & $10 \%$ & -2.57 & -2.91 \\
\hline & & $5 \%$ & -2.86 & -3.22 \\
\hline & & $2.5 \%$ & -3.13 & -3.5 \\
\hline & & $1 \%$ & -3.43 & -3.82 \\
\hline
\end{tabular}

As seen, ECT (-1) is negative and significant as expected. Thus, this confirms the existence of the cointegration relationship between serials. ECT(-1) is equal to ( -0.48$)$. It means, according to Model 2, the short-run imbalances are eliminated in the long-run and the

Year 5/ 2021, Volume-5, Issue-2 | WWW.ispecjournal.org

1. This study presented orally in the BILTEK International Symposium-IV; held on April 12-13, 2021 at Gaziantep University, Nizip Faculty of Education, Gaziantep, Turkey. 
system is converging to the long-run equilibrium. Thus, $48 \%$ of the short-term imbalances are eliminated every two periods ( in other word 6 months ).

\section{Summary and Conclusion}

In this study, it is researched whether the leverage ratio in Turkish banking sector is influenced from the procyclicality in the Turkish economy or not by ARDL (Auto-Regresive Distributed Lag) method or known bounds test method for first time with the quarterly banking cumulative sectoral data between 2007 - 2019. For this purpose, it is focused on the relationship between the leverage ratio and the total loans / total asset rate. As leverage ratio, it is used the external assets / total shareholder's equity rate and also the total assets / total shareholder's equity. As asset rate is used the total loans / total assets in banking sector. To conclude, it is confirmed that there is a positive and statistically significant relationship between each of leverage ratio and asset in the long run in Turkey's banking sector by ARDL Method. The leverage ratio is procyclical. It means when the leverage ratio increase and also the ratio of total credits to total assets in banking sector increase. The findings for short run provide additional information as well. ECT(-1) is negative and statistically significant. It shows that the cointegration models converge to equilibrium in a short time. As a result, as the credit policy, it is recommended to determine countercyclical policy and or a countercyclical capital buffers to build up additional capital reserves during financial expansion periods by using leverage ratios, especially by combining the leverage ratios with Basel capital rules. Otherwise, the procylicality of the leverage in banking sector can threaten the financial system stability or the bank-based Turkish financial system and so economy.

\section{REFERENCES:}

Adrian, T. and Shin, H.S. (2008a). "Liquidity and financial cycles". BIS Working Paper no: 256.

Adrian, T. and Shin, H. S. (2008b). "Liquidity, monetary policy, and financial cycles". Current issues in economics and finance, 14 (1).

Adrian, T. and Shin, H.S. (2010). " Liquidity and leverage ". Journal of financial intermediation, 19 (3), 418 - 437.

Athanasoglou, P. P., Daniilidis, I., and Delis, M. D. (2014). “ Bank procyclicality and output: Issues and policies ". Journal of Economics and Business, 72, 58 - 83.

Avc1, E., and Çatak, Ç.(2016). "Determinants of Bank Capital Structure and Procyclicality of Leverage: an Empirical Analysis from Turkey". Marmara Business Review, 1 (2), 4157.

Baglioni, A., Beccalli, E., Boitani, A., and Monticini, A. (2013). "Is the leverage of European banks procyclical?”. Empirical Economics, 45 (3), 1251 - 1266.

Basel Committee (2014). "Basel III leverage ratio framework and disclosure requirements". Retrieved from https://www.bis.org/publ/bcbs270.pdf on 14.05.2021.

Year 5/ 2021, Volume-5, Issue-2 | WWW.ispecjournal.org

1. This study presented orally in the BILTEK International Symposium-IV; held on April 12-13, 2021 at Gaziantep University, Nizip Faculty of Education, Gaziantep, Turkey. 
BIS (2008). "Addressing financial system procyclicality: a possible framework". Note for the FSF Working Group on Market and Institutional Resilience. Retrieved from https://www.fsb.org/wp-content/uploads/r_0904e.pdf on 16.05.2021.

BIS (2009a). 2008 Annual Report ( 79th Annual Report ). Retrieved from https://www.bis.org/publ/arpdf/ar2009e.pdf on 15.05.2021.

BIS (2009b). "The role of valuation and leverage in procyclicality", CGSF Papers no: 34. Retrieved from https://www.bis.org/publ/cgfs34.pdf on 15.05.2021.

Binici, M. , and Köksal, B. (2012). “Is the leverage of Turkish banks procyclical?”. Central Bank Review, 12 (2), 11.

BRSA(2021) Monthly Banking Sector Data, https://www.bddk.org.tr/Data/MonthlyBulletin/21, Retrieved from https://www.bddk.org.tr/BultenAylik

Çalışkan, A. (2011). "Leverage Behaviour of Turkish Banks: How Did They Escape the Global Crisis?”. Available at SSRN 2723867.

D’Hulster, K. (2009). “The Leverage Ratio”. Crisisresponse public policy for private sector. Retrieved from http://documents1.worldbank.org/curated/en/260961468158726436/pdf/530440BRI 0Cris10Box345594B01PUBLIC1.pdf on 06.01.2021.

Greene, W. H. (2002). Econometric Analysis. Maxwell Macmillan International.

Hardouvelis, G. A. (2010). “Actions for a less procyclical financial system”. Economy \& Markets, Eurobank Research, 5 (5) , 1 - 33. Retrieved from https://hardouvelis.gr/wpcontent/uploads/2017/12/ECONOMYMARKETSSeptember2010.pdf on 09.04.2021.

Hasan, A., and Nasır, Z. M. (2008). "Macroeconomic Factors and Equity Prices: An Empirical Investigation by Using ARDL Approach". The Pakistan Development Review, 501-513. Retrieved from http://thepdr.pk/pdr/index.php/pdr/article/viewFile/2283/2283 on 08.04.2021.

Kalemli-Ozcan, S., Sorensen, B., and Yesiltas, S. (2012). “Leverage across firms, banks, and countries ". Retrieved from NBER Working Paper 17354. https://www.nber.org/system/files/working_papers/w17354/w17354.pdf on 06.01.2021.

Kaya, E. and Köksal,Y.(2018). “Türk Bankacılık Sisteminde Kaldıraç Döngüselliği”. İşletme Ekonomi ve Yönetim Araştırmaları Dergisi, 1 (2), 7 - 20.

Kaya, E., and Köksal, Y. (2019). "Kaldıraç ve Döngüsellik: Bankacılık Sektörü Üzerine Bir Uygulama”. Eskişehir Osmangazi Üniversitesi İktisadi ve İdari Bilimler Dergisi, 14 (2), $331-346$.

Landau, J. P.(2009, May). "Procyclicality: what it means and what could be done". In remarks at the Bank of Spain's conference on Procyclicality and the Role of Financial Regulation, Madrid, May. Retrieved from

Year 5/ 2021, Volume-5, Issue-2 | WWW.ispecjournal.org

1. This study presented orally in the BILTEK International Symposium-IV; held on April 12-13, 2021 at Gaziantep University, Nizip Faculty of Education, 
http://eia.libis.lt:8080/archyvas/viesas/20091230051056/http://www.banquefrance.fr/gb/instit/telechar/discours/2009/090504.pdf on 05.04.2021.

Mert, M. and Çağlar, A.E. (2019). Eviews ve Gauss Uygulamalı Zaman Serileri Analizi. Detay Yayıncilık, Ankara.

Narayan, P. K. (2005). "The Saving and Investment Nexus for China: Evidence from Cointegration Tests". Applied economics, 37 (17), 1979 - 1990. Retrieved from https://www.researchgate.net/profile/PareshNarayan/publication/24075564_The_Saving_and_Investment_Nexus_for_China_Evi dence_From_Cointegration_Tests/links/568ab37a08ae051f9afa6bb7/The-Savingand-Investment-Nexus-for-China-Evidence-From-Cointegration-Tests.pdf on 27.01.2020.

Nijathaworn, B. (2009). "Rethinking procyclicality-what is it now and what can be done?" In Presentation by Mr Bandid Nijathaworn, Deputy Governor of the Bank of Thailand, at the BIS/FSI-EMEAP High Level Meeting on "Lessons Learned from the Financial Crisis-An International and Asian Perspective", Tokyo (Vol. 30).

Nkoro, E. and Uko, A. K. (2016). "Autoregressive Distributed Lag (ARDL) cointegration technique: application and interpretation". Journal of Statistical and Econometric methods, 5 (4), 63-91. $\quad$ Retrieved from http://www.scienpress.com/Upload/JSEM/Vol\%205_4_3.pdf on 28.01.2020.

Nuño, G., and Thomas, C. (2017). "Bank leverage cycles". American Economic Journal: Macroeconomics, $9 \quad$ (2), 32-72. $\quad$ Retrieved from https://www.econstor.eu/bitstream/10419/153957/1/ecbwp1524.pdf on 08.01.2021.

Özdamar, G. (2015). "Türkiye Ekonomisinde Döviz Kuru Geçiş Etkisi: ARDL-Sınır Testi Yaklaşımı Bulguları". Akdeniz Üniversitesi iktisadi ve idari Bilimler Fakültesi Dergisi, 15 ( 32 ), 66 - 97.

Pesaran, M. H., and Shin, Y. (1998). "An Autoregressive Distributed-Lag Modelling Approach to Cointegration Analysis". Econometric Society Monographs, 31, 371 - 413.

Pesaran, M. H., Shin, Y., and Smith, R. J. (2001). "Bounds Testing Approaches to the Analysis of Level Relationships". Journal of applied econometrics, 16 (3), 289 - 326.

Ouattara, B.(2004a). "Modelling the long run determinants of private investment in Senegal (No. 04 / 05)”. Credit Research Paper.

Ouattara, B. (2004b). The impact of project aid and programme aid inflows on domestic savings: A case study of Côte d'Ivoire. In Centre for the Study of African Economies Conference on Growth, Poverty Reduction and Human Development in Africa.

Year 5/ 2021, Volume-5, Issue-2 | WWW.ispecjournal.org

1. This study presented orally in the BILTEK International Symposium-IV; held on April 12-13, 2021 at Gaziantep University, Nizip Faculty of Education, Gaziantep, Turkey. 


\section{ISSN 2717-7262 ISPEC Journal of Social Sciences \& Humanities}

TBB (2021). Bankalarımız 2020. Yayın no: 339. Retrieved from https://www.tbb.org.tr/Content/Upload/Dokuman/7766/Bankalarimiz_2020.pdf $\quad$ on 15.05.2021.

Terzioglu, M., and Demir, Y. (2015). "Leverage Procyclical of Turkish Deposit Banks". Journal of Economics Finance and Accounting, 2 (4). Retrieved from https://dergipark.org.tr/en/pub/jefa/issue/32437/360752 on 06.01.2021.

Wu, Y., and Hu, R. (2017). "A Study of The Leverage Pro-cyclical Behavior and Asymmetry of Commercial Banks in China”. Revista de Cercetare ŞiInterventie Sociala, 59 (12), 136 - 152. Retrieved from https://www.rcis.ro/images/documente/rcis59_10.pdf on 07.01.2021. 